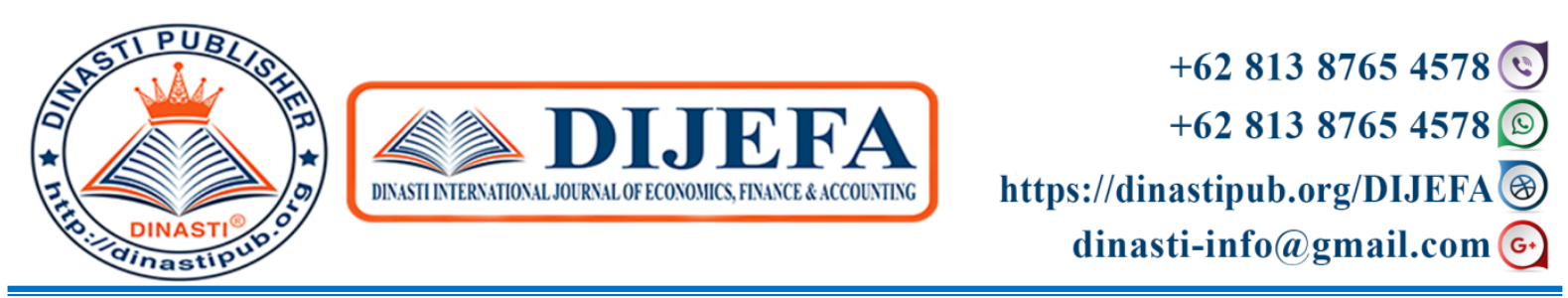

\title{
KNOWLWEDGE OF TAXATION AND FISCUS SERVICE ON TAXPAYERS COMPLIANCE
}

\author{
Kartika Pratiwi Putri ${ }^{1}$, Meita Chandra Devi ${ }^{2}$, Dodi Tisna Amijaya ${ }^{3}$ \\ 1) Winayamukti University, West Java, Indonesia \\ ${ }^{2)}$ Winayamukti University, West Java, Indonesia \\ ${ }^{3)}$ Winayamukti University, West Java, Indonesia
}

\begin{tabular}{|c|l|}
\hline $\begin{array}{c}\text { ARTICLE INFORMATION } \\
\text { Received: 05 March 2020 } \\
\text { Revised: 16 March 2020 } \\
\text { Issued: 22 March 2020 }\end{array}$ & $\begin{array}{l}\text { Abstract: Achievement of Indonesia's tax income is } \\
\text { faced with various obstacles so that it has not been } \\
\text { able to meet the desired target. Compliance of } \\
\text { taxpayers is an important factor for sources of state } \\
\text { income to reach the state budget. The purpose this } \\
\text { research is to determine wether there is a significant } \\
\text { influence on knowledge of taxation and fiscus service } \\
\text { against taxpayer compliance. This research uses a } \\
\text { descriptive survey method involving 100 respondents } \\
\text { Kartika Pratiwi Putri } \\
\text { of taxpayers through a questionnaire at Bandung tax } \\
\text { office. The measured variable data included } \\
\text { knowledge of taxation and fiscus services and } \\
\text { continued by using multiple linear regression analysis. } \\
\text { The results of the study prove that the level of } \\
\text { knowledge of taxation and fiscus services affect } \\
\text { partially tax compliance by 3.5\% and fiscus services } \\
\text { by 57.2\%. Simultaneous is influenced by knowledge } \\
\text { of taxation and fiscus services by } 60.7 \% \text { and by 39.3\% } \\
\text { influenced by other factors. } \\
\text { Keywords: Knowledge, Fiscus Services, Compliance }\end{array}$ \\
\hline
\end{tabular}

\section{INTRODUCTION}

In the State Budget (APBN) made by the government together with the DPR, there are three sources of revenue that are the mainstay, namely;

1) Revenue from the tax sector

2) Revenue from the oil and gas sector

3) Revenue from non-tax sector

Of the three sources of revenue above, revenue from the tax sector is one of the largest sources of state revenue. (Widodo, 2010). Tax contribution to state revenue is very dominant in the state budget, this happens because tax is a definite source of contributing 
funds to the state because it is a reflection of the mutual cooperation of the public in state funding governed by legislation. (Widodo, 2010).

Based on Ministry of Finance data quoted by CNBC Indonesia, Friday (8/24/2018), the last time tax revenue reached the target did occur in fiscal 2008. At that time, the realization of tax revenue reached Rp 571 trillion or $106.7 \%$ of the target set at Rp 535 trillion. Below is growth of Target and Realization of Tax Revenue and tax ratio data from Year 2012-2015. (Asmara, 2018).

\section{Graph 1 Target and Realization of Tax Revenue Year 2012-2015}

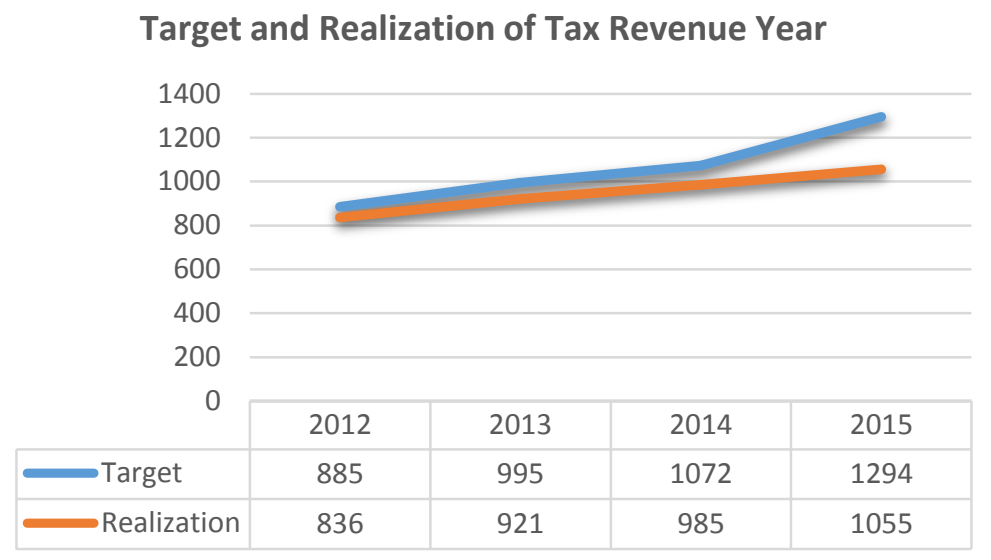

Source : processed data

In the year 2012 realization of IDR 836 trillion or $94.5 \%$ of the target of IDR 885 trillion. In the year 2013 realization of IDR 921 trillion or $92.6 \%$ of the target of IDR 995 trillion. In the year 2014 realization of IDR 985 trillion or $91.9 \%$ of the target of IDR 1,072 trillion. In the year 2015 realization of IDR 1,055 trillion or $81.5 \%$ of the target of IDR 1,294 trillion, decrease from last year. The realization of tax revenue did not reach the APBN target is caused by many factors, one of which is the constraints of taxpayers, especially in terms of compliance in meeting taxpayer obligations, namely paying taxes. The reality in Indonesia shows that the level of compliance is still low. This can be seen from the suboptimal tax revenue that is reflected in the tax ratio. (Siregar, 2011).

Graph 2 Tax Ratio Year 2012-2015

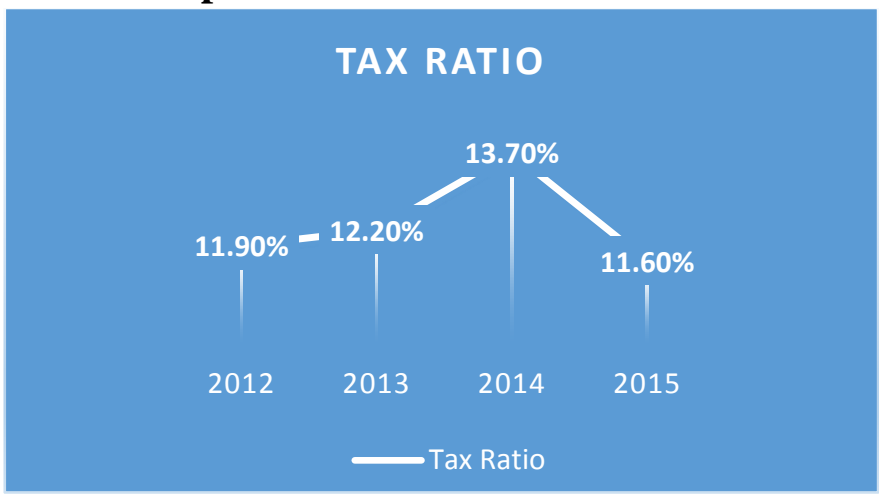

Source : processed data

The ratio of tax revenue to gross domestic product (GDP), or commonly known as tax ratio since year 2012 to 2014 tax ratio increase. In 2014, the tax ratio was recorded to be quite high up to $13.7 \%$ but declined in 2015, Indonesia's tax ratio was at 11.6\%. (Asmara, 2018). 
In terms of tax ratio, the ratio between tax revenue and national income or gross domestic product (GDP), is also still below the standard set by the World Bank at $15 \%$.

The development of the submission of the Annual Tax Return and the ratio of compliance of corporate taxpayers and individual taxpayers in 2012-2014 in the regional office of the City of Bandung, it can be seen below.

Table 1 The Annual Tax Return and the ratio of compliance of corporate taxpayers and Individual Taxpayers 2012-2014

\begin{tabular}{|l|r|r|r|r|r|r|r|r|r|}
\hline \multirow{2}{*}{ Tax office } & \multicolumn{3}{|c|}{$\begin{array}{c}\text { Number of Registered } \\
\text { Taxpayers (corporate and } \\
\text { Individuals) }\end{array}$} & \multicolumn{2}{|c|}{$\begin{array}{c}\text { Total Annual Tax Returns } \\
\text { entered }\end{array}$} & \multicolumn{2}{c|}{$\begin{array}{c}\text { Ratio of compliance to } \\
\text { taxpayers (\%) }\end{array}$} \\
\cline { 2 - 11 } & $\mathbf{2 0 1 2}$ & $\mathbf{2 0 1 3}$ & $\mathbf{2 0 1 4}$ & $\mathbf{2 0 1 2}$ & $\mathbf{2 0 1 3}$ & $\mathbf{2 0 1 4}$ & $\mathbf{2 0 1 2}$ & $\mathbf{2 0 1 3}$ & $\mathbf{2 0 1 4}$ \\
\hline $\begin{array}{l}\text { Madya } \\
\text { Bandung }\end{array}$ & 1.043 & 1.124 & 1.278 & 706 & 756 & 744 & 67,68 & 73,82 & 58,21 \\
\hline $\begin{array}{l}\text { Pratama } \\
\text { Bojonegara }\end{array}$ & 91.548 & 93.426 & 105.342 & 38.432 & 37.256 & 38.496 & 41,98 & 39,87 & 36,54 \\
\hline $\begin{array}{l}\text { Pratama } \\
\text { Cibeunying }\end{array}$ & 99.937 & 102.598 & 113.839 & 40.400 & 39.628 & 37.960 & 40,41 & 38,62 & 33,34 \\
\hline $\begin{array}{l}\text { Pratama } \\
\text { Cicadas }\end{array}$ & 111.892 & 117.892 & 136.115 & 47.548 & 45.089 & 43.944 & 42,68 & 38,24 & 32,28 \\
\hline $\begin{array}{l}\text { Pratama } \\
\text { Karees }\end{array}$ & 108.166 & 113.639 & 125.414 & 40.596 & 39.335 & 41.238 & 36,36 & 36,28 & 30,96 \\
\hline $\begin{array}{l}\text { Pratama } \\
\text { Tegalega }\end{array}$ & 78.679 & 82.181 & 95.161 & 32.348 & 32.290 & 32.048 & 41,11 & 39,29 & 33,67 \\
\hline
\end{tabular}

Source : processed data

Based on table above it can be concluded that there is still a lack of compliance by taxpayers in carrying out their tax obligations. Although each year the number of registered taxpayers (corporate taxpayers and personal taxpayers) increases, the annual amount received by the tax office is not proportional to the number of registered taxpayers, therefore it can be said that the ratio of compliance to taxpayers is low.

The level of tax compliance that is still low is one of the obstacles in efforts to increase state revenue in the tax sector, there are still many taxpayers who do not report and pay their taxes. (Mangoting, 2013).

Indonesia needs 95 thousand tax employees. But the number of tax officers (Fiscus) that there are only 33 thousand people, less when compared to the number of taxpayers who reached 25 million people (personal taxpayers) and 2 million corporate taxpayers. When compared with the number of tax officers (tax authorities), the ratio reaches 1: 818 or an employee serves 818 taxpayers. (Putri, 2014). This resulted in the tax officer being not optimal with the limitations of tax officials.

The purpose this research is to determine wether there is a significant influence on knowledge of taxation and fiscus service against taxpayers compliance.

\section{LITERATURE REVIEW}

\section{Taxpayer Compliance}

Tax compliance can be defined as a condition where taxpayers fulfill all tax obligations and carry out their tax rights. (Numantu, 2005). According to (Marziana M, 2010) tax compliance can be defined as the degree to which a taxpayer complies or fails to comply with the tax rules of their country. (Nasucha, 2004) revealed that taxpayer compliance as 
Guilt and shame, taxpayers' perceptions of fairness and tax burdens they bear, and the effect of satisfaction on government services.

Based on research (Chan, 2000) carried out a survey to compare compliance behavior between Hong Kong and US taxpayers. They found that the US respondents decision to comply with tax laws were primarily driven by age and education, which in turn positively influenced moral development and attitude. In contrast, Hong Kong respondents have shown negative influenced. According to (Kurniawan, 2006) factors that encourage tax compliance consist of a factor of knowledge or understanding of taxpayers regarding taxation.

Tax compliance is influenced by intention to comply. While the intention to comply is influenced by the attitude towards tax compliance, subjective norms, and perceived behavioral control. In changing the culture and creating voluntary tax compliance should be approached psychologically to taxpayers, because associated with things that exist within the taxpayer. In addition, psychological approaches should be taken remembering that in a democracy country (in this case Indonesia) the relationship between taxpayers and tax authorities is a psychological contract. Psychological contract requires an equal relationship between the taxpayer and the tax collector and the success depends on how much taxpayers and tax officers have mutual trust (Damayanti, 2012).

\section{Knowledge Of Taxation on Taxpayers Compliance}

Tax knowledge according to (Yulianawati, 2011) is the step of maturing the mind of a taxpayer through teaching and training efforts. This is in agreement with the statement (Kasipillai, 2003) education will provide the necessary tax knowledge to comply with the tax matter and change the perceptions and attitudes towards tax-compliance by creating more positive attitudes. Research by (Inasius, 2015) shows that tax knowledge has a positive effect on tax compliance and a significant effect on individual taxpayer compliance.

Tax knowledge and tax compliance among the taxpayers are an essential requirements in implementing Self Assessment System (SAS) as well as continuous, consistent and compulsory tax education among the taxpayers. (Palil, 2005). Therefore, the level of tax education and tax knowledge is significant to ensure that the tax administration to be going well. As a result, taxpayers will able to assess their tax liability correctly and to file tax return forms on time. (Ahmad, 2013).

According to (Kasippilai, 2000) tax knowledge is an essential element in a voluntary compliance tax system. (Eriksen, 1996) believed that with reasonable understanding of the tax laws, people are willing to respect the tax system, consequently they are more compliant to pay tax instead of evading it. Furthermore, individuals become educated, which is knowledgeable in the aspect of tax planning, tax law and the likes. At the same time, tax knowledge improved individual's awareness and ethics toward reduce their tendencies of tax noncompliance. According to there are many factors that influence taxpayer's compliance, but knowledge is the main affecting factor particularly the self-assessment system.

Research conducted by (Aji, 2014) regarding the effect of perceptions of the implementation of the tax census, knowledge of tax regulations, and awareness of taxation on taxpayers in the Special Region of Yogyakarta shows that knowledge of tax regulations has a significant positive effect on taxpayer compliance. The problem that occurs at the current taxpayers is their lack of understanding of the tax obligations that they must fulfill. The higher the level of taxpayer knowledge, the higher the level of taxpayer compliance because taxpayers already know the tax obligations that they must fulfill. 
H1: The knowledge of taxation has influence on taxpayers compliance

\section{Fiscal Services on Taxpayers Compliance}

Fiscus service all forms of public service activities carried out by government agencies at the central, in the regions and in the environment of State / Regional Government Enterprises in the form of goods and services both in the context of efforts to meet the needs of the community and in the context of implementing statutory regulations. (Rahayu, 2010). A fiscus service must have the ability to serve, possess a friendly attitude. Taxpayers must be treated like a customer in a company that must be maintained and maintained so that they are still willing to pay taxes. In the self-assessment system, the willingness and cooperation of taxpayers in carrying out tax obligations is a very important thing. DGT must create trust and compliance between the tax authorities and taxpayers in carrying out tax administration. (Widodo, 2010).

Tax or fiscal services are important for helping tax obligations. If the quality of government services tax or tax authorities is good, then it will not be better than expected. (Utaminingsih, 2014). The results of research conducted by (Siregar, 2011) shows the influence of the fiscal services on taxpayer compliance. The treatment or services provided by the tax officer affect tax compliance. The better the state (or in this case represented by the fiscus service) treats taxpayers, the higher the taxpayer's incentive to comply. (B. Bawono Kristiaji, 2013). Research result (Muratc, 2014) of aside from having a decent and profesional tax administration infrastructure, the employees, who are in direct contact with the taxpayers should have common sense and be able to empathize with the tax payers and therefore should increase their intentness in paying taxes.

$\mathrm{H} 2$ : Fiscus service has influence on taxpayers compliance

\section{RESEARCH METHODS}

The research method used in this study is a questionnaire or survey method. The research conducted is descriptive and verification research. Descriptive aims to provide an overview of the research variables and verification research aims to test the truth of the hypothesis by collecting data in the field. In this study the test is knowlwedge of taxation and fiscus service on taxpayers compliance.

The population in this study is corporate taxpayers and individual taxpayers who are registered at the Bandung Tax Office. The sample in this study were 100 individual taxpayers and corporate taxpayers registered in KPP Bandung.

Research data can be obtained from primary and secondary sources. The data in this study were obtained from the results of the distribution of questionnaires from research objects namely corporate taxpayers and individual taxpayers who were registered at KPP Bandung. Whereas secondary data is information collected by researchers from indirect sources, such as data from the Directorate General of Taxes, journals, literature, and other means related to the topic under study.

\section{Validity Test}

Validity is a measure that indicates the level of reliability or validity of a measuring instrument. To test the validity of the measuring instrument, first look for the correlation price between the parts of the measuring instrument as a whole by correlating each item measuring instrument with a total score which is the sum of each item, with the Pearson Product Moment formula as follows (Arikunto, 2002); 


$$
\mathrm{r}_{\text {count }}=\frac{\mathrm{n}\left(\sum \mathrm{XY}\right)-\left(\sum \mathrm{X}\right) \cdot\left(\sum \mathrm{Y}\right)}{\sqrt{\left\{\mathrm{n} \cdot \sum \mathrm{X}^{2}-\left(\sum \mathrm{X}\right)^{2}\right\} \cdot\left\{\mathrm{n} \cdot \sum \mathrm{Y}^{2}-\left(\sum \mathrm{Y}\right)^{2}\right\}}}
$$

As:

$\mathrm{r}_{\text {count }}=$ Correlation coefficient

$\sum X \mathrm{X}=$ The total score of the item

$\sum \mathrm{Yi}=$ Total total score (all items)

$\mathrm{n} \quad=$ Number of respondents

Next calculated by the $n-t$ test with the formula:

$\mathrm{t}$ calculated $=\mathrm{r} \sqrt{\mathrm{n}-2}$

$$
\sqrt{n-2}
$$

\section{As:}

$\mathrm{t}=\mathrm{t}$ value calculated

$\mathrm{r}=$ The correlation coefficient of the result $\mathrm{r}$ is calculated

$\mathrm{n} \quad=$ Number of respondents

Distribution (Table $\mathrm{t})$ for $\alpha=0.10$ and degree of freedom $(\mathrm{dk}=\mathrm{n}-2)$

Decision rule: If $t$ calculated $>\mathrm{T}$ table means valid, vice versa

$\mathrm{t}$ calculated $<\mathrm{t}$ table means invalid

\section{Reliability Test}

(Arikunto, 2002) Instruent reliability test with a range of scores between 1 to 5 using the Cronbach Alpha coefficient test tool with the following formula:

$\mathrm{r}_{11}=\left[\frac{k}{k-1}\right]\left[1-\frac{\sum \sigma_{b}^{2}}{v_{t}^{2}}\right]$

As:

$\mathrm{r}_{11} \quad=$ instrument reliability

$\mathrm{k}=$ the number of questions or the number of questions

$\sum \sigma_{b}^{2} \quad=$ number of item / item variants

$v_{t}^{2} \quad=$ varian total

The data obtained were processed using the regression analysis method. The multiple linear regression equation according to (Sugiyono, 2009).

$\mathrm{Y}=$ dependent variable (tax compliance)

$$
\mathbf{Y}=\mathbf{a}+\mathbf{b}_{1} \mathbf{X}_{1}+\mathbf{b}_{2} \mathbf{X}_{2}
$$

$\mathrm{a}=$ constant number

$b_{1}, b_{2}=$ regression coefficient knowledge of taxpayers and Fiscus Services

$\mathrm{X}_{1}=$ independent variable $\mathrm{X}_{1}$ (knowlwedge of taxation)

$\mathrm{X}_{2}=$ free variable $\mathrm{X}_{2}$ (Fiscus Service)

To obtain the accuracy of the regression equation model, a classic assumption test is needed. This assumption test consists of three tests namely: normality test, multicollinearity test, and heteroscedasticity test.

According (Sugiyono, 2009) the following guidelines for providing correlation coefficient interpretation:

Tabel 2 Guidelines For Providing Interpretation Correlation Coefficients

\begin{tabular}{|c|c|}
\hline Interval & Relationship Level \\
\hline $0,00-0,199$ & Lowest \\
\hline $0,20-0,399$ & Low \\
\hline
\end{tabular}




\begin{tabular}{|c|c|}
\hline $0,40-0,599$ & Medium \\
\hline $0,60-0,799$ & Strong \\
\hline $0,80-1,000$ & Strongest \\
\hline
\end{tabular}

Source : Sugiyono

\section{FINDINGS AND DISCUSSION}

Testing the validity of the instruments in this study was carried out with the help of the statistical package software SPSS (Statistical Package For Social Science) version 17.0 with the following results;

Table 3 Research Instrument Validity Test Results

\begin{tabular}{|c|c|c|c|c|}
\hline Variabel & No & r count & r critic & Conclusion \\
\hline \multirow{5}{*}{ knowledge of taxation $\left(X_{1}\right)$} & III.1.1 & 0,663 & 0,368 & valid \\
\cline { 2 - 5 } & III.1.2 & 0,719 & 0,368 & valid \\
\cline { 2 - 5 } & III.1.3 & 0,777 & 0,368 & valid \\
\cline { 2 - 5 } & III.1.4 & 0,694 & 0,368 & valid \\
\cline { 2 - 5 } & III.1.5 & 0,675 & 0,368 & valid \\
\hline \multirow{5}{*}{ Fiscus Service $\left(X_{2}\right)$} & III.2.1 & 0,714 & 0,368 & valid \\
\cline { 2 - 5 } & III.2.2 & 0,731 & 0,368 & valid \\
\cline { 2 - 5 } & III.2.3 & 0,629 & 0,368 & valid \\
\cline { 2 - 5 } & III.2.4 & 0,629 & 0,368 & valid \\
\cline { 2 - 5 } & III.2.5 & 0,733 & 0,368 & valid \\
\hline \multirow{5}{*}{ Taxpayers Compliance (Y) } & III.3.1 & 0,441 & 0,368 & valid \\
\cline { 2 - 5 } & III.3.2 & 0,509 & 0,368 & valid \\
\cline { 2 - 5 } & III.3.3 & 0,432 & 0,368 & valid \\
\cline { 2 - 5 } & III.3.4 & 0,563 & 0,368 & valid \\
\cline { 2 - 5 } & III.3.5 & 0,683 & 0,368 & valid \\
\cline { 2 - 5 } & III.3.6 & 0,630 & 0,368 & valid \\
\cline { 2 - 5 } & III.3.7 & 0,622 & 0,368 & valid \\
\cline { 2 - 5 } & III.3.8 & 0,464 & 0,368 & valid \\
\cline { 2 - 5 } & III.3.9 & 0,614 & 0,368 & valid \\
\hline
\end{tabular}

Source : data processed in SPSS 17,0

The whole coefficient of validity is greater than 0.368 so it can be concluded that all questions used in the study of the three variables are declared valid and can be used as a tool for data collection in this study.

Reliability test with the aim to determine the consistency of the degree of dependence and stability of the measuring instrument are using SPSS 17.0 with the following results;

Table 4 Test Results of Research Variable Reliability

\begin{tabular}{|l|c|c|c|}
\hline Variabel & r count & r critic & Conclusion \\
\hline knowledge of taxation $\left(\mathrm{X}_{1}\right)$ & 0,740 & 0,700 & Reliabel \\
\hline Fiscus Service $\left(\mathrm{X}_{2}\right)$ & 0,712 & 0,700 & Reliabel \\
\hline Taxpayers Compliance $(\mathrm{Y})$ & 0,709 & 0,700 & Reliabel \\
\hline
\end{tabular}

Source : data processed in SPSS 17,0 
The reliability test results above obtained by the Cronbach alpha value of $0.740 ; 0.712$; and 0.709 . The third value of the reliability coefficient is greater than 0.700 that all questions used have been able to measure and have been tested for validity and eligibility so that all questions that represent each variable are feasible to be used as a measurement of research.

\section{Descriptive statistics}

Table 5 Recapitulation of Respondents' Answer Results in the knowledge of taxation

\begin{tabular}{|c|c|c|c|c|c|c|c|c|c|c|c|c|c|c|}
\hline \multirow[b]{3}{*}{ No } & \multicolumn{10}{|c|}{ Alternatif Answer } & & & \multirow[b]{3}{*}{$\%$} & \multirow{3}{*}{ Interpretation } \\
\hline & \multicolumn{2}{|c|}{$\mathbf{A}$} & \multicolumn{2}{|c|}{ B } & \multicolumn{2}{|c|}{$\mathbf{C}$} & \multicolumn{2}{|c|}{ D } & \multicolumn{2}{|r|}{$\mathbf{E}$} & \multicolumn{2}{|c|}{ Indeks score } & & \\
\hline & $\mathbf{f}$ & $\%$ & f & $\%$ & f & $\%$ & f & $\%$ & $\mathbf{f}$ & $\%$ & Actual & Ideal & & \\
\hline 1 & 77 & 77,00 & 16 & 16,00 & 7 & 7,00 & 0 & 0,00 & 0 & 0,00 & 470 & 500 & 94 & Strongest \\
\hline 2 & 73 & 73,00 & 17 & 17,00 & 8 & 8,00 & 2 & 2,00 & 0 & 0,00 & 461 & 500 & 92,2 & Strongest \\
\hline 3 & 76 & 76,00 & 13 & 13,00 & 9 & 9,00 & 1 & 1,00 & 1 & 1,00 & 462 & 500 & 92,4 & Strongest \\
\hline 4 & 61 & 61,00 & 21 & 21,00 & 14 & 14,00 & 4 & 4,00 & 0 & 0,00 & 439 & 500 & 87,8 & Strongest \\
\hline 5 & 64 & 64,00 & 21 & 21,00 & 12 & 12,00 & 2 & 2,00 & 1 & 1,00 & 445 & 500 & 89 & Strongest \\
\hline & & & & nowled & of 1 & axation & & & & & 2277 & 2500 & 91,08 & Strongest \\
\hline
\end{tabular}

The overall percentage obtained on the taxpayer knowledge of taxpayers is $91.09 \%$ and it is classified as the strongest.

Table 6 Recapitulation of Respondents' Answer Results in Fiscus Service

\begin{tabular}{|c|c|c|c|c|c|c|c|c|c|c|c|c|c|c|}
\hline \multirow[b]{3}{*}{ No } & \multicolumn{10}{|c|}{ Alternatif Answer } & & & \multirow[b]{3}{*}{$\%$} & \multirow{3}{*}{ Interpretation } \\
\hline & \multicolumn{2}{|c|}{$\mathbf{A}$} & \multicolumn{2}{|c|}{ B } & \multicolumn{2}{|r|}{$\mathbf{C}$} & \multicolumn{2}{|c|}{ D } & \multicolumn{2}{|r|}{$\mathbf{E}$} & \multicolumn{2}{|c|}{ Indeks score } & & \\
\hline & $\mathbf{f}$ & $\%$ & $\mathbf{f}$ & $\%$ & $\mathbf{f}$ & $\%$ & f & $\%$ & $\mathbf{f}$ & $\%$ & Actual & Ideal & & \\
\hline 1 & 75 & 75,00 & 11 & 11,00 & 11 & 11,00 & 3 & 3,00 & 0 & 0,00 & 458 & 500 & 91,6 & Strongest \\
\hline 2 & 79 & 79,00 & 12 & 12,00 & 1 & 1,00 & 8 & 8,00 & 0 & 0,00 & 462 & 500 & 92,4 & Strongest \\
\hline 3 & 78 & 78,00 & 13 & 13,00 & 8 & 8,00 & 1 & 1,00 & 0 & 0,00 & 470 & 500 & 94 & Strongest \\
\hline 4 & 51 & 51,00 & 27 & 27,00 & 11 & 11,00 & 11 & 11,00 & 0 & 0,00 & 418 & 500 & 83,6 & Strong \\
\hline 5 & 69 & 69,00 & 10 & 10,00 & 14 & 14,00 & 7 & 7,00 & 0 & 0,00 & 441 & 500 & 88,2 & Strongest \\
\hline & & & & & Ius & ervice & & & & & 2249 & 2500 & $\mathbf{8 9 , 9 6}$ & Strongest \\
\hline
\end{tabular}

The overall score percentage obtained on the Fiscus Service is $89.96 \%$ and it is classified as the strongest.

Table 7 Recapitulation of Respondents' Answer Results in Taxpayers Compliance

\begin{tabular}{|c|c|c|c|c|c|c|c|c|c|c|c|c|c|c|}
\hline \multirow[b]{3}{*}{ No } & \multicolumn{10}{|c|}{ Alternatif Answer } & & & \multirow{3}{*}{$\%$} & \multirow{3}{*}{ Interpretation } \\
\hline & \multicolumn{2}{|c|}{$\mathbf{A}$} & \multicolumn{2}{|c|}{ B } & \multicolumn{2}{|c|}{ C } & \multicolumn{2}{|c|}{ D } & \multicolumn{2}{|c|}{$\mathbf{E}$} & \multicolumn{2}{|c|}{ Indeks score } & & \\
\hline & $\mathbf{F}$ & $\%$ & $\mathbf{F}$ & $\%$ & $\mathbf{f}$ & $\%$ & $\mathbf{F}$ & $\%$ & $\mathbf{F}$ & $\%$ & Actual & Ideal & & \\
\hline 1 & 67 & 67,00 & 18 & 18,00 & 12 & 12,00 & 3 & 3,00 & 0 & 0,00 & 452 & 900 & 50,2 & Lowest \\
\hline 2 & 61 & 61,00 & 21 & 21,00 & 12 & 12,00 & 6 & 6,00 & 0 & 0,00 & 449 & 900 & 50 & Lowest \\
\hline 3 & 80 & 80,00 & 13 & 13,00 & 4 & 43,00 & 3 & 3,00 & 0 & 0,00 & 473 & 900 & 52,3 & Medium \\
\hline 4 & 64 & 64,00 & 22 & 22,00 & 11 & 11,00 & 3 & 3,00 & 0 & 0,00 & 447 & 900 & 49,6 & Lowest \\
\hline 5 & 59 & 59,00 & 25 & 25,00 & 13 & 13,00 & 3 & 3,00 & 0 & 0,00 & 443 & 900 & 49,2 & Lowest \\
\hline 6 & 65 & 65,00 & 21 & 21,00 & 7 & 7,00 & 7 & 7,00 & 0 & 0,00 & 444 & 900 & 49,3 & Lowest \\
\hline 7 & 60 & 60,00 & 28 & 28,00 & 11 & 11,00 & 1 & 1,00 & 0 & 0,00 & 447 & 900 & 49,6 & Lowest \\
\hline 8 & 37 & 37,00 & 34 & 34,00 & 18 & 18,00 & 11 & 11,00 & 0 & 0,00 & 397 & 900 & 44,1 & Lowest \\
\hline 9 & 57 & 57,00 & 17 & 17,00 & 19 & 19,00 & 7 & 7,00 & 0 & 0,00 & 424 & 900 & 47,1 & Lowest \\
\hline & & & & axpay & rs C & mplia & & & & & 3976 & 8100 & 49,08 & Lowest \\
\hline
\end{tabular}


Based on table above, it can be seen that the overall score obtained in the taxpayer compliance variable is $49.08 \%$, and it is classified as the lowest.

\section{Analysis of Multiple Correlation Coefficients}

Multiple correlation coefficient analysis is used to measure the relationship that occurs between the independent variable with the dependent variable.

\section{Table 8 Multiple Correlation Coefficient}

Model Summary ${ }^{b}$

\begin{tabular}{|l|r|r|r|r|r|}
\hline Model & \multicolumn{1}{|c|}{ R } & R Square & $\begin{array}{c}\text { Adjusted R } \\
\text { Square }\end{array}$ & $\begin{array}{c}\text { Std. Error of the } \\
\text { Estimate }\end{array}$ & Durbin-Watson \\
\hline 1 & $.779^{9}$ & .607 & .559 & 2.70692 & 1.712 \\
\hline
\end{tabular}

a. Predictors: (Constant), (Fiscus Service X2), knowledge of taxpayers (X1)

b. Dependent Variable: tax compliance (Y)

source : data processed in SPSS 17,0

Based on table above, information is obtained that the correlation value (R) obtained between knowledge of taxation on tax compliance is 0.779 . The interval value of 0.779 according to (Sugiyono, 2009) is at an interval of 0.60-0.799 included in the strong category. So it can be concluded that there is a strong relationship between the knowledge of taxation towards taxpayers compliance in the tax office in Bandung.

Determination Coefficient Analysis ( $\left(\mathbf{R}^{2}\right)$

Determination Coefficient Analysis (KD) is used to see how much the independent variable $(\mathrm{X})$ influences the dependent variable (Y).

Table 9 Coefficient of Determination (R-square)

Model Summary ${ }^{b}$

\begin{tabular}{|l|r|r|r|r|r|}
\hline Model & $\mathrm{R}$ & R Square & \multicolumn{1}{c|}{$\begin{array}{c}\text { Adjusted R } \\
\text { Square }\end{array}$} & $\begin{array}{c}\text { Std. Error of the } \\
\text { Estimate }\end{array}$ & Durbin-Watson \\
\hline 1 & $.779^{\mathrm{a}}$ & .607 & .559 & 2.70692 & 1.712 \\
\hline
\end{tabular}

a. Predictors: (Constant), (Fiscus Service X2), knowledge of taxpayers (X1)

b. Dependent Variable: tax compliance (Y)

source : data processed in SPSS 17,0

Table above SPSS output results above, note the coefficient of determination or R square of 0.607 or $60.7 \%$. This shows that knowledge of taxation simultaneously influence on taxpayers compliance of $60.7 \%$, while the rest of $100 \%-60.7 \%=39.3 \%$ is the influence of other variables not examined. The interval value of 0.607 according to (Sugiyono, 2009) is at an interval of 0.60-0.799 included in the strong category. To find out the effect of each independent variable on the dependent variable partially, the beta value is multiplied by zero order, where the beta value is the standardized regression coefficient value and zero order is the correlation coefficient value of each independent variable $(\mathrm{X})$ with dependent variable (Y).

Table 10 Partial Determination Coefficient

Coefficients $^{\mathrm{a}}$

\begin{tabular}{|cl|c|c|}
\hline \multirow{2}{*}{ Model } & & \multicolumn{1}{c|}{$\begin{array}{c}\text { Standardized } \\
\text { Coefficients }\end{array}$} & Correlations \\
\cline { 3 - 4 } & & Beta & Zero-order \\
\hline 1 & $\begin{array}{l}\text { (Constant) } \\
\text { Knowledge of taxation (X1) }\end{array}$ & .110 & .314 \\
& & & \\
\hline
\end{tabular}




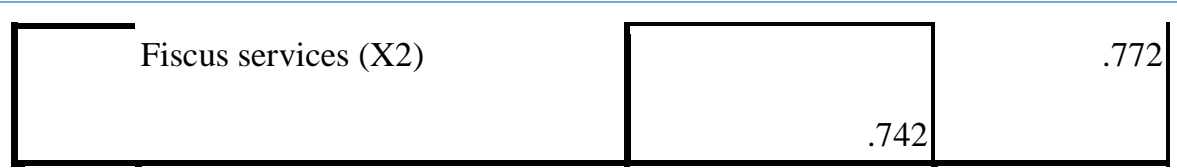

a. Dependent Variable: tax compliance Y)

source : data processed in SPSS 17,0

Following are the results of the partial effect between the independent variables on the dependent variable with the beta $\mathrm{X}$ zero order formula:

Knowledge of Taxpayer Variable $=0.110 \times 0.314=0.035$ or $3.5 \%$.

Fiscus Service Variable $=0.742 \times 0.772=0.572$ or $57.2 \%$.

Based on the calculation above, it is known that the variable knowledge of taxation $\left(\mathrm{X}_{1}\right)$ influences taxpayers compliance (Y) with a contribution of $3.5 \%$ with an interval value of 0.035 according to (Sugiyono, 2009) at an interval of 0,20-0.399 included in the low category and variable Fiscus Services $\left(\mathrm{X}_{2}\right)$ of $57.2 \%$ with an interval value of 0.572 according to (Sugiyono, 2009) at an interval of 0.40-0.599 included in the medium category.

The Influence of knowledge of taxation and Fiscus Service on Taxpayers Compliance

Based on the table of the SPSS output above, the coefficient of determination or R square are 0.607 or $60.7 \%$, it shows that the knowledge of taxation simultaneously influence the taxpayers compliance of $60.7 \%$, while the rest of $100 \%-60.7 \%=39.3 \%$ is the influence of other variables not examined.

Noting the results of the aforementioned research reinforces the results of research conducted by (Utaminingsih A. A., 2014) that the service of the tax apparatus or the tax authorities is crucial to the compliance of taxpayers. If the service quality of the tax authorities or the tax authorities is good, then it does not rule out the compliance of taxpayers will also improve. The results of research conducted by (Siregar, 2011) show the influence of tax authorities on tax compliance. The treatment or services provided by the tax authorities affect tax compliance. The better the state (or in this case represented by the tax authorities) treats taxpayers, the higher the taxpayer's drive to comply. (B. Bawono Kristiaji, 2013). The same thing in the research results of (Muratc, 2014) that tax employees (tax officials) must have the nature to be sympathetic to taxpayers so that taxpayers feel comfortable and motivated to pay taxes.

\section{Knowledge Of Taxation On Taxpayer Compliance}

Based on the table above the results of partial influence between the independent variables on the dependent variable with the beta formula $\mathrm{X}$ zero order: variable knowledge of taxation $=0.110 \times 0.314=0.035$ or $3.5 \%$. Based on the results of statistical calculations, it is known that the knowledge of taxation $\left(\mathrm{X}_{1}\right)$ has an effect of $3.5 \%$ on taxpayers compliance (Y), while the rest of $100 \%-3.5 \%=96.5 \%$ is influenced by other variables. The results of research conducted by (Suyanto, 2014) that tax knowledge is something important for taxpayers to have. If taxpayers are aware and know about the importance, benefits and objectives of tax payments made to the state, then taxpayers voluntarily make tax payments in an orderly and timely manner. The same thing was expressed by (Nazir, 2010) the level of tax knowledge has a positive and significant effect on taxpayer compliance.

\section{Fiscus Services on Taxpayer Compliance}

The results of the partial effect between the independent variables on the dependent variable with the formula beta $X$ zero order: fiscal services $=0.742 \times 0.772=0.572$ or $57.2 \%$. Based on the results of statistical calculations, it is known that the fiscus service variable gives an effect of $57.2 \%$ on taxpayer compliance (Y), while the remaining $100 \%-57.2 \%=$ 
$42.8 \%$ is influenced by other variables. The results of research conducted by (Harjanti Puspa Arum, 2012) the fiscus service have a positive and significant impact on tax compliance. The same thing was expressed by (Iga, 2014) Based on the results of the study, it can be concluded that tax audits, awareness, and service quality have a positive effect on compliance.

\section{CONCLUSION AND SUGESTION}

Based on the results of the discussion the authors draw conclusions knowledge of taxpayer and fiscus services are simultaneously and partially influences on taxpayers compliance. Based on the results of the discussion and conclusions above, the authors suggest to increase the level of taxation knowledge of taxpayers, the DGT needs to conduct regular education and outreach in both urban and bandung areas in rural areas so that there is an even distribution of basic tax knowledge. Fiscus must act professionally and be ready to serve taxpayers well. Providing professional services so that taxpayers feel valued and in the end will raise awareness to pay taxes which will have an impact on tax compliance. To improve taxpayer compliance in Bandung, KPP in Bandung must provide counseling so that taxpayers know correctly how to carry out tax obligations.

\section{REFERENCE}

Arikunto, S. (2002). Research Procedure A Practical Approach. Jakarta: Rineka Cipta.

B. Bawono Kristiaji, T. F. (2013). Understanding Tax Non-compliance in Inside Tax 14. North Jakarta: PT.Dimensi Internasional Tax.

Kurniawan, P. \&. (2006). Tax Collection in Indonesia. Malang: Bayumedia.

Numantu, S. (2005). Introduction to Taxation. Jakarta: Granit.

Sugiyono. (2009). Statistics for Research. Bandung: Alfabeta.

Widodo, W. ( 2010). Moralitas, Budaya dan kepatuhan Pajak. . Bandung: Alfabeta.

Ahmad, M. R. (2013). The Perception of Tax Payers on Tax Knowledge and Tax Education with Level of Tax Compliance:A Study the Influences of Religiosity. ASEAN Journal of Economics, Management and Accounting 1 (1), 118-129 .

Aji, A. C. (2014). The Influence of Perception on the Implementation of the National Tax Census, Knowledge of Tax Regulations, and Tax Awareness on Taxpayer Compliance in Special Region of Yogyakarta. . Journal of Accounting Volume 2, Number 1.

Chan, C. W. (2000). An Expanded Model of Taxpayer Compliance: Empirical Evidence from the US and Hong Kong. Journal of, 83-103.

Damayanti, T. W. (2012). Changes in Indonesian Tax Culture, Is There a Way? Study Through Planned Theory of Behavior. International Referees Research Journal. Vol.ii, 4th Edition.

Eriksen, K. a. (1996). Tax Knowledge and Attitudes towards Taxation: A Report on a Quasi - Experiment. Journal of Economic Psychology, 17, 387-402.

Harjanti Puspa Arum, Z. (2012). The Influence of Taxpayer Awareness, Fiscus Services, and Tax Sanctions on the Compliance of Individual Taxpayers Conducting Business 
Activities and Free Employment (Study in Kpp Pratama Cilacap Area). Diponegoro Journal of Accounting .

Iga, L. S. (2014). Effects of Tax Examination, Awareness, Service Quality at the Compliance Level of Corporate Taxpayers. E-Journal of Udayana University Accounting.

Inasius, F. (2015). Tax Compliance of Small Medium Enterprises in Indonesia. Business and Economic Volume 10, Issue 1.

Kasipillai, J. N. (2003). The Influence of education on tax avoidance and tax evasion. Journal of tax research volume 1 . Number 2, 134-146.

Kasippilai, J. (2000). Taxpayer knowledge index as a clue for non-compliance. Journal on Pakistan's Taxation Laws.

Kusmuriyanto, S. d. (2014). The Influence of Knowledge of Taxation, Firmness of Taxation Penalties and Tax Justice on SME Tax Obligations in Semarang City. Journal of Accounting Analysis 3 (3).

Mangoting, C. J. (2013). . Pengaruh Kesadaran Wajib Pajak, Kualitas Pelayanan Fiskus, Sanksi Perpajakan, Lingkungan Wajib Pajak Berada terhadap Kepatuhan Wajib Pajak Orang Pribadi di Surabaya. Tax \& Accounting Review, Volume 1, Nomor 1.

Marziana M, N. A. (2010). Perception of Taxpayers With Level of Compliance: A Comparison in the East Coast Region, Malaysia. Journal of Global Business and Economics, Vol.1, issue 1, 241-257.

Muratc, N. S. (2014). Factors Affecting Tax Compliance of Taxpayers: The Role of Tax Officers The Case of Istanbul and Canakkale. Business and Economics Research Journal Volume 5 Number 2, 19-31.

Nasucha, C. (2004). Public Administration Reform: Theory and Practice. Jakarta: PT. Gramedia Widiasarana Indonesia.

Nazir, N. (2010). Effect of Tax Knowledge and Tax Administration Systems Against Taxpayer Compliance. Journal of Information, Taxation, Accounting and Public Finance (JIPAK) Volume 5, Number 2.

Palil, M. R. (2005). Taxpayers Knowledge: A Descriptive Evidence On Demographic Factors in Malaysia. Accounting \& Finance Journal, Vol. 7, No. 1, 11-21.

Rahayu, S. K. (2010). Indonesian Taxation Formal Concepts and Aspects. Yogyakarta: Graha Ilmu.

Siregar, P. a. (2011). The Effect of Fiscus Services and the Implementation of Sunset Policy on Taxpayer Compliance in Efforts to Increase Taxes. Journal of Business Economics (JEB), Volume 5, Number 2.

Suyanto, T. W. (2014). Effects of Taxation Knowledge, Education Level, and Administrative Sanctions on Taxpayer Compliance in Paying Land and Building Taxes. Accounting journal.

Tiraada, T. A. (2013). Kesadaran Perpajakan, Sanksi Pajak, Sikap Fiskus Terhadap Kepatuhan WPOP Di Kabupaten Minahasa Selatan. EMBA. Volume 1, Nomor 3.

Utaminingsih, A. A. (2014). The Effect of Tax Sanctions and Service of Tax Apparatuses on Taxpayer Compliance with Risk Preference as Moderation Variables. Accounting Analysis Journal 3 (2). 
Yulianawati, P. H. (2011). Factors That Affect Will to Pay Taxes. Financial and Banking Dynamics Volume 3, Number 1.

Asmara, C. G. (2018, October Monday). CNBC Indonesia, A Transmedia Company. Retrieved from CNBC Indonesia: https://www.cnbcindonesia.com/market/2018102217220717-38505/target-pajak-yang-tak-pernah-tembus-di-4-tahun-jokowi-jk

Putri, T. A. (2014, october Monday). tempo.co. Retrieved from bisnis.tempo.co: http://www.tempo.co/read/news/2014/10/13/087614000/Penerimaan-Pajak-Baru-65Persen-dari-Target. 